\title{
Research on Optimizing the Tax Business Environment - Taking Shunde Taxation Bureau's Innovation Reform as an Example
}

\author{
Yi Yang, Xinyun Li*, Simin Huang \\ State Administration of Taxation, Foshan Shunde District Taxation Bureau, Foshan 528300, Guangdong Province, China \\ *Corresponding author: Xinyun Li, lixinyun222@163.com

\begin{abstract}
Since 2013, optimizing the business environment has become China's national strategy. In recent years, the Party and the government have continuously introduced a series of new measures such as the "streamline administration, delegate power, strengthen regulation, and improve services" reform to promote the continuous optimization of the business environment. As an important part of the business environment, the tax business environment is of great significance to improve the business environment and promote economic development. By analyzing the current situation of the tax business environment in China, this article discusses the existing problems in the process of optimizing tax business environment in China. Taking Shunde Taxation Bureau's innovative reform of tax business environment optimization as an example, this article introduces the practical innovation and promotion of optimizing tax business environment from four aspects: promoting convenience, digitalization, legalization, and intensive reform, in order to provide relevant experience for the optimization of tax business environment in other areas of China.
\end{abstract}

Keywords: Tax business environment; Tax collection and management reform; Shunde Taxation Bureau; Tax payment service

Publication date: October 2021; Online publication: October 29, 2021

\section{Introduction}

In 2006, the World Bank added a tax business environment index to the Business Environment Report to measure and evaluate the tax business environment of an economy. Since then, the tax business environment has become an important part of the business environment ${ }^{[1]}$. Tax business environment is of great significance to both economic promotion and social development. It does not only objectively reflect the various costs of enterprises, but also guide the flow of production factors and influence the tax compliance of enterprises. In the Business Environment Report 2020 released by the World Bank, China's tax business environment ranked 105th among the recorded 190 economies, which is 9 places higher than that in 2019. It can be seen that with the great attention and continuous improvement of China's tax authorities, the tax business environment has been optimized, but there is still more room for improvement [2].

On March 24, 2021, the General Office of the Central Committee of the Communist Party of China (CPC) and the General Office of the State Council issued the Opinions on Further Deepening the Reform of Tax Collection and Management (hereinafter referred to as Opinions). With the promulgation of the Opinions, exploring the construction of a new system of tax and fee services has gradually become a key issue that the tax authorities in China need to pay attention to in the process of optimizing the tax business environment. Shunde District, a district in Foshan at Guangdong Province is as an innovative experimental 
area entrusted by the Guangdong Provincial Party Committee and government to implement the new development concept as well as build a high-quality mechanism and system reform in shouldering the heavy responsibility to deepen the reform of tax collection and management. Under this background, the Taxation Bureau of Shunde District, State Taxation Administration of The People's Republic of China (hereinafter referred to as Shunde Taxation Bureau) focuses on the tasks of higher authorities and combines the local actual situation. Innovating the reform of tax collection and management and promoting the reform of convenience, digitalization, legalization, as well as intensification on the basis of constructing a new tax service system have successfully optimized the tax business environment in Shunde District, Foshan. The exploration of this innovation provides valuable experience for the optimization of the tax business environment system at other regions in China.

\section{Status quo of China's tax business environment}

By understanding the present situation of the tax business environment in China, a foundation can be laid to analyze the problems existing in the optimization process of China's tax business environment.

\subsection{Evaluation index of tax business environment}

At present, the world's most consensus index of tax business environment evaluation has been put forward by the World Bank in its Business Environment Report. The World Bank uses the "tax payment" index to evaluate the advantages and disadvantages of the tax business environment of the economy. Under this index, there are four secondary indicators to evaluate the tax payment of the economy ${ }^{[3]}$. The specific contents of these four secondary indicators are shown in Table 1, which include tax payment times, tax payment time, total tax rate and social contribution rate, as well as post-tax return process.

Table 1. Four secondary indicators of "tax payment"

\begin{tabular}{ll}
\hline \multicolumn{1}{c}{ Indicator } & \multicolumn{1}{c}{ Contents } \\
\hline Tax payment times & $\begin{array}{l}\text { The number of tax payment reflects the complexity and frequency of payment methods, referring } \\
\text { to the number of times required by standard enterprises to pay various taxes and fees, such as value- } \\
\text { added tax (VAT), enterprise income tax, and social insurance premiums within one year. }\end{array}$ \\
\hline \multirow{2}{*}{ Tax payment time } & $\begin{array}{l}\text { Tax payment time is recorded according to the number of hours per year. This index measures the } \\
\text { time required by standard enterprises to prepare, declare, and pay enterprise income tax, personal } \\
\text { income tax, value-added tax, and social security premiums throughout the year. }\end{array}$ \\
\hline \multirow{3}{*}{ Total tax rate and } & $\begin{array}{l}\text { Total tax and contribution rate refers to the ratio of various taxes and fees that standard enterprises } \\
\text { must pay to commercial profits. It measures the amount of taxes and compulsory payments paid by } \\
\text { standard enterprises in the second year of operation, which is expressed by the share of commercial } \\
\text { profits. }\end{array}$ \\
\hline Post-tax return process & $\begin{array}{l}\text { Post-tax return process index refers to the time required for enterprises to apply for VAT refund } \\
\text { and obtain tax refund after tax declaration, the time required for enterprises to find errors in } \\
\text { declaration and correct declaration after enterprise income tax settlement, as well as the possible } \\
\text { audit time of enterprise income tax. }\end{array}$ \\
\hline
\end{tabular}

Source: Organized by the World Bank's Business Environment Report 2020

\subsection{Analysis of China's tax business environment}

By analyzing the ranking and scores of the "tax payment" index in the Business Environment Report of the World Bank from 2017 to 2020, the specific situation of the current tax business environment in China can 
be clearly understood as shown in Table 2 (since the World Bank only included the post-tax return process index into the "tax payment" index from 2017, the ranking and scores of China's "tax payment" index in the Business Environment Report issued by the World Bank from 2017 to 2020 were selected for analysis).

Table 2. The scores and rankings of China's "tax payment" index in the Business Environment Report from 2017 to 2020

\begin{tabular}{ccccccc}
\hline Year & $\begin{array}{c}\text { Tax payment } \\
\text { times } \\
\text { (times/year) }\end{array}$ & $\begin{array}{c}\text { Tax payment } \\
\text { time } \\
\text { (hours/year) }\end{array}$ & $\begin{array}{c}\text { Total tax rate and } \\
\text { social contribution } \\
\text { rate (\%) }\end{array}$ & $\begin{array}{c}\text { Post-tax return } \\
\text { process index }\end{array}$ & $\begin{array}{c}\text { Tax } \\
\text { indicator } \\
\text { score }\end{array}$ & $\begin{array}{c}\text { Ranking of "tax } \\
\text { payment" index } \\
\text { (first name) }\end{array}$ \\
\hline 2017 & 9 & 259 & 68 & 48.62 & 60.46 & 131 \\
2018 & 9 & 207 & 67.3 & 49.08 & 62.90 & 130 \\
2019 & 7 & 142 & 64.9 & 50 & 67.53 & 114 \\
2020 & 7 & 138 & 59.2 & 50 & 70.10 & 105 \\
\hline
\end{tabular}

Data source: According to the Business Environment Report of the World Bank from 2017 to 2020.

It can be seen from Table 2 that the number of tax payments, the tax payment time, as well as the total tax rate and social contribution rate in China decreased year by year; the tax payment time reduced from 259 hours per year in the 2017 to 138 hours per year in 2020; the tax payment times reduced from 9 times per year in 2017 to 7 times per year in 2020; the total tax rate and social contribution rate reduced from $68 \%$ in 2018 to $59.2 \%$ in 2020 . However, after tax filing, the process index increased year by year, from 48.62 in 2017 to 50 in 2020. In addition, it can be seen from Table 2 that the score of China's "tax payment" index increased from 60.46 in 2017 to 70.10, which fully reflects the progress of the tax business environment in China. Although the ranking of the "tax payment" index in China rose from 131 in 2017 to 105 in 2020, it still lags behind most economies evaluated in the Business Environment Report of the World Bank, implying that there is still a long way to go in optimizing the tax business environment in China.

\section{Problems in the process of optimizing the tax business environment in China}

From the foregoing analysis, although the optimization of tax business environment in China has achieved certain results, there is still much more room for improvement. The specific problems are as follows:

\subsection{The degree of facilitation of tax payment needs to be improved}

On the one hand, although most tax authorities have made great achievements in business standardization and standard unification, there are still cases where taxpayers need to run errands because of the core elements and lack of secondary materials in tax matters relating to individual businesses. In actual taxation process, in order to avoid risks, tax authorities sometimes require taxpayers to submit materials again on the basis of "other materials required by tax authorities." This makes it difficult for taxpayers to get through the "last mile" of the taxation process. On the other hand, the post-epidemic era has put forward higher requirements for taxpayers in handling business across regions because the "non-contact" tax service promoted by tax authorities has certain requirements in regard to taxpayers' tax ability, tax groups with low frequency of tax matters, low degree of tax specialization are faced with operational barriers, and a certain entry threshold in enjoying digital tax dividends.

\subsection{Imperfect digital tax service system}

In the era of digital economy, the mode of taxation through network platform has become the first choice 
for most taxpayers. However, the developed online taxation platform has many problems, such as multisource, unstable operation, imperfect function, and insufficient service support, which are not conducive to the improvement of work efficiency and the overall planning of tax service ${ }^{[4]}$. For example, there are data barriers between some tax systems, which do not fully realize data interconnection and intercommunication, resulting in insufficient application of big data technology and unable to realize the support of information technology for tax business. In another example, in the process of vigorously promoting the digital upgrading and transformation of the manufacturing industry as well as implementing the strategy of manufacturing a strong country, a large number of traditional manufacturing enterprises are facing digital transformation. Higher requirements have been put forward for tax business environment, but the current digital tax service system is unable to provide suitable services for manufacturing enterprises in the transition period; the lack of support has affected the process of digital upgrading and transformation of the manufacturing industry.

\subsection{The level of tax legalization needs to be improved}

At present, the problems existing in the construction of tax legalization are mainly manifested in the lack of cross-departmental cooperation between tax authorities and judicial organs, the lack of standardized law enforcement behavior of tax departments, as well as the lack of corresponding guarantee mechanism for the implementation of tax business environment optimization policies ${ }^{[5]}$. First of all, the cooperation mechanism between tax authorities and judicial organs is imperfect. In terms of data sharing and exchange, it is impossible to realize interdepartmental information exchange, which leads to the failure to protect the legitimate rights and interests of taxpayers. Secondly, the tax authorities are not standardized in the administrative law enforcement process, such as the openness of administrative law enforcement. Moreover, some tax officials may abuse their power in the process of law enforcement. It has seriously affected the process of tax legalization. Finally, although China has already combed a number of policies to optimize the tax business environment in detail and introduced the Regulations on Optimizing the Business Environment, which was promulgated by the State Council on October 22, 2019, and implemented from January 1, 2020, onwards, to continuously optimize the business environment, liberate and develop social productive forces, as well as accelerate construction of the modern economic system in promoting a high quality development, there are still unclear rights and responsibilities in the process of the specific implementation of the policy; thus, the policy cannot be implemented in place.

\subsection{Unformed pattern of tax cooperation and co-governance}

On the one hand, in the era of digital economy, the rapid development of information technology has spawned a large number of new business models, and taxpayers' demand for tax services has also been increasing. With the strength of tax authorities alone, it is difficult to break the existing tax collection and management mode, accurately meet the needs of taxpayers, judge the tax-related risks faced by different types of taxpayers, as well as provide targeted solutions. On the other hand, the establishment of the tax credit system in China is imperfect. The tax credit system cannot effectively connect with other social credit systems and the linkage mechanism of the credit system that has been formed at present needs to be optimized. In addition, the information sharing, joint incentive, and the disciplinary mechanism between multiple departments need to be further investigated. It does not give full play to the promotion of taxpayers' conscious compliance.

\section{Optimizing the tax business environment of innovative practices by Shunde Taxation Bureau}

In order to solve the above problems and realize the working goal to change from an undifferentiated service 
to a refined, intelligent, and personalized service, Shunde Taxation Bureau has formed a resolution on the working idea of "striving for pilot plus independent innovation," and with the support of higher-level bureaus, the whole city has taken the lead in building a demonstration bureau to create a first-class tax business environment and develop a high-quality service manufacturing industry. Shunde Taxation Bureau is vigorously promoting the construction of a new tax and fee service system with reform ideas and innovative methods by implementing 13 strategies and striving to bring out more innovative achievements with the leading role of demonstration. The details are shown in Figure 1.

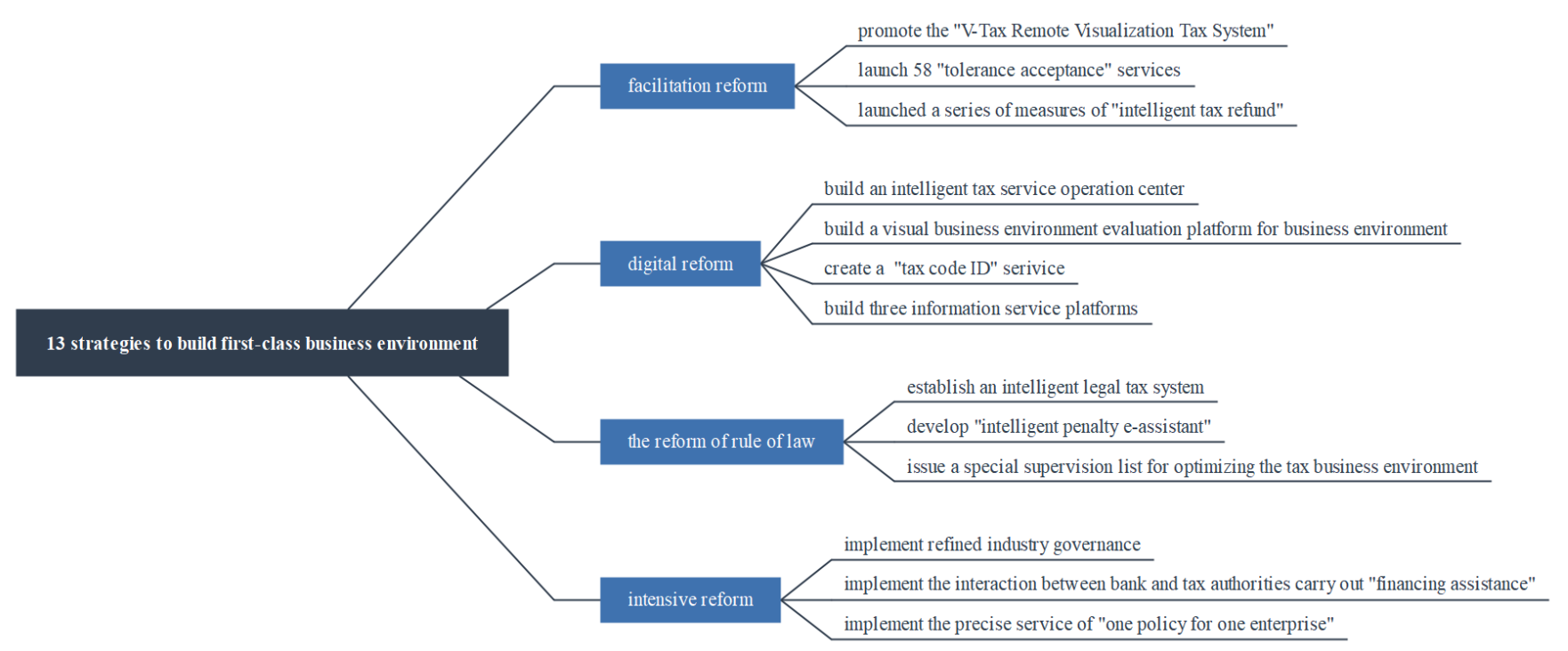

Figure1. Thirteen strategies of Shunde Taxation Bureau in optimizing the business environment

\subsection{Promoting facilitation reform and creating a new experience of convenient taxation}

In order to continuously deepen the reform of "streamline administration, delegate power, strengthen regulation, and improve services," Shunde Taxation Bureau has innovated and introduced facilitation measures in tax payment, which has successfully simplified the tax process and tax information for taxpayers. First, it continues to promote the "V-Tax Remote Visualization Tax System" (hereinafter referred to as V-Tax system), so as to realize the concept of "running at most once." In the system, noncontact taxation functions such as offline processing and co-frequency help are introduced, and the offline window manual service is transferred online to promote tax-related real estate transactions to go online. On this basis, aiming at the old, the weak, the sick, the disabled, and other groups who have difficulties in using non-contact taxation, the extension of the V-Tax system to the "doorway office" network of government service is actively explored, and convenience tax points in administrative service centers, banks, as well as commercial complexes are deployed to meet the tax demand and lower the threshold of non-contact tax use. Second, 58 "tolerance acceptance" businesses have been launched, and the taxation process has been simplified. The expansion of these 58 businesses, such as issuing VAT invoices, benefit in the application of "tolerance acceptance" mechanism, promotion of data tolerance, and realization of "zero provision" of relevant business processing data through government information sharing. Third, it has launched a series of measures of "intelligent tax refund" to shorten the tax refund time by more than half. The innovative export tax rebate management auxiliary platform of "smart refund," the VAT retention and refund platform of "I benefit refund," the tax refund guardian of "cloud refund," the risk-oriented management of export tax rebate, as well as the "enterprise tax remittance and refund" have been integrated into a series of measures of "smart quick refund," which successfully optimized the process of "refunding all due." 


\subsection{Promoting digital reform and establishing a new intelligent taxation system}

Shunde Taxation Bureau is keeping up with the digital development trend, continuously promoting the deep integration of smart taxation and "digital government," running through the whole process of tax collection and management with the concept of administering taxes by numbers, maximizing the driving force of big data, making use of the technical support of big data, cloud computing, etc., as well as actively exploring and creating a high-integration function, high security performance, and intelligent taxation with high application efficiency. First, an intelligent tax service operation center can be built to provide "one-stop" services for enterprises. With the centralized operation center as the service center, the operation mode of "resource intensive management, free setting at the front desk, and unified acceptance at the back desk" in regard to tax payment service can be built along with all kinds of declaration software, such as Yueshuitong, which are connected to the management platform in a unified way, forming a new pattern of intelligent taxation with decentralization and centralization as well as improving the efficiency of tax and fee handling. Second, a visual business environment evaluation platform can be built to make the business environment clear at a glance. On the one hand, the manufacturing digital transformation index has been launched, which is based on tax-related information data. A two-dimensional model of "enterprise as the point and region as the block" is built to comprehensively and accurately reflect the digital transformation of the manufacturing industry and serve the transformation as well as upgrading of the regional manufacturing industry. On the other hand, business confidence index has also been launched. By closely following the "tax payment" index in the business environment evaluation, double coefficients of objective business confidence index and competent business confidence index have been designed. It is important to regularly measure and investigate large enterprises, timely and intuitively grasp the business confidence index of large enterprises in the region, as well as explore refined evaluation criteria in order to create a first-class business environment. The third is to create enterprise-specific tax codes to help develop services, so that A-level tax credit enterprises can gain more opportunities for development through "bright codes." By selecting tax credit rating, tax scale, the increase of tax amount, etc., and using blockchain technology to generate two-dimensional code tax business cards would show good credit information for high-quality enterprises through active "bright code" in foreign operations. The fourth is to build information service platforms, so that enterprises can enjoy a smooth service experience. For example, developing an information platform of "creating and enjoying the easy" ensures a more satisfactory digital transformation of enterprises. Another example is to create a social security "smart" mediation mechanism to ensure a more secure protection of labor rights and interests, as well as to create the country's first village reform platform-urban renewal tax guide code, so that the village reform can attract more worry-free investments.

\subsection{Promoting the reform of the rule of law and creating a new environment of the rule of law and fairness}

The rule of law is an important breakthrough to optimize the tax environment. In order to promote the reform of tax business environment under the rule of law, Shunde Taxation Bureau has made innovative explorations from three aspects: improving the protection of legitimate rights and interests of market subjects, promoting the standardization of law enforcement behavior, and ensuring the implementation of business environment optimization policies. The first is to establish an intelligent legal and tax system. The pattern of co-governance between judicial organs and tax authorities needs to be deepened and expanded, and the protection of legitimate rights and interests of market entities needs to be improved. In addition to integrating and upgrading the existing "one base and two systems," smoothing the information feedback mechanism of second-hand houses, as well as upgrading the function of Foshan tax property inspection and control network, Shunde Taxation Bureau also explored the establishment of a joint mediation mechanism for dispute mediation by expanding the scope of information sharing lists implemented in cooperation with 
courts and clarifying the method of tax burden of judicial auction. Second, an "intelligent penalty e-assistant" has been developed to promote the standardization of law enforcement behavior, and a new tax law enforcement mechanism has been established with the integration of legal principles and conditions. On the premise of following the principles of legality, fairness, openness, and reasonableness, Shunde Taxation Bureau automatically would be able to judge and measure the degree of tax administrative punishment by using the power of informationization. It would also be beneficial to realize the standardized and intelligent management of tax administrative punishment as well as shorten the processing time of taxpayers' business. Third, the special supervision list for optimizing the tax business environment has been issued, and the responsibility has been compacted to ensure that the measures are effective. In addition to innovating the "escort plus" supervision and guarantee mechanism, strengthening communication and cooperation with the Commission for Discipline Inspection and Supervision, as well as issuing a supervision list around optimizing the tax business environment, a large-scale investigation activity has also been organized to optimize the tax business environment, and special rectification work has been carried out for "microcorruption" around the masses. In addition, in order to ensure the implementation of the tax business environment policy, a smart supervision platform has been set up to combine the special supervision of tax law enforcement with daily supervision to optimize the implementation of the tax business environment policy. Ensure that every key measure in optimizing the business environment is accountable to people.

\subsection{Promoting intensive reform and constructing a new pattern of collaborative governance}

In order to solve the problems of imperfect establishment of the tax credit system and insufficient tax cooperation among different departments, Shunde Taxation Bureau has been promoting intensive reform innovatively, using the idea of integration, expanding and extending from strengthening departmental cooperation and social cooperation, as well as continuously improving the level of collaborative tax administration, so as to accurately identify the needs of taxpayers and effectively reduce the risk of taxrelated fees. It is important to further strengthen the establishment of the tax credit system. The first step is to implement a refined industry governance and create a new tax-enterprise relationship of "no risk and no disturbance." On the one hand, through the implementation of the Industry-to-Industry Action Plan, the tax-related risks of various characteristic industries in the manufacturing industry are accurately identified and positioned. Linkage intermediaries, industry associations, and other third-party forces provide taxpayers with service reminders, correction reminders, and other risk prevention reminders, as well as make every effort to get through the difficulties, pain points, and blocking points in tax administration of characteristic industries. On the other hand, the three-dimensional governance model of "triple governance" has been implemented and the "high efficiency" of invoice management services has been realized. By establishing an inter-departmental professional governance service team, focusing on priority governance in key areas, highlighting governance in key industries, and managing key issues for a long time would ensure no risk and no disturbance, as well as help enterprises prevent and control risks in time such as false invoicing. Second, the interaction between bank and tax has been established to help finance and build a social credit system. Innovating the service mode of "internet plus taxation plus finance" further improves the service quality, coverage, and efficiency of "silver-tax interaction," actively links financial institutions, explores to benefit more market players, allows more taxpayers to enjoy honest tax dividends through "silver-tax interaction" on the premise of complying to the laws and regulations, as well as improves taxpayers' tax compliance on the basis of legal popularization. Third, the precise service of "one enterprise, one policy" has been implemented and a tax-related risk prevention and control network has been built. By building a tax compliance cooperation system, selecting large enterprises with mature conditions in their jurisdictions, jointly developing the first tax-related risk prevention system that is universally applicable to large enterprises in the whole province and even the whole country, as well as supporting the chief liaison 
officer and special reporting system of large enterprises would benefit large enterprises prevent tax risks and reduce tax compliance costs.

\section{Conclusion and enlightenment}

Business environment is not only an important embodiment of a country's soft power, but also a support for a country to enhance its comprehensive strength and promote high-quality economic development. As one of the core indicators for evaluating business environment, tax business environment is of great significance to the creation of a high-quality business environment. By analyzing the specific situation of the current tax business environment in China, it has been found that although the optimization of the tax business environment in China has achieved certain results, the ranking of the "tax payment" index still lags behind most economies in the world. In regard to that, there are still some problems faced by the current tax business environment in China, such as insufficient facilitation of tax payment, imperfect digital tax service system, the urgent need to improve the level of tax legalization, unbalanced supply and demand of tax service, as well as an imperfect tax credit system. In the process of optimizing the tax business environment, Shunde Taxation Bureau, as the pathfinder and vanguard of tax reform in Guangdong Province, is constructing a new tax service system and focusing on promoting the reform of convenience, digitalization, rule of law, and intensification by implementing thirteen innovative strategies to accurately meet the needs of taxpayers. In terms of improving the quality and efficiency of tax service, promoting the digital development of tax service, solidly establishing the tax rule of law, and deepening tax cooperation and co-governance, this article explores a demonstration path to optimize the tax business environment, which provides valuable experience for the optimization of the tax business environment in other regions of China. In the process of exploring ways to optimize the tax business environment in other regions of China, Shunde's innovative tax practices can be regarded as a blueprint in combination with the actual situation in each region. It is important to e xplore the exclusive path that conforms to the construction of local tax business environment and jointly promote the high-quality development of China's economy with a high-quality tax business environment.

\section{Disclosure statement}

The authors declare that there is no conflict of interest.

\section{References}

[1] Zhang J, Lin W, 2020, Research on the Optimization of Tax Business Environment from the Perspective of Governance. Tax Research, (09): 22-26.

[2] Shao S, Shao C, 2021, Research on the Path of Tax "Release, Management and Service" to Improve the Business Environment - Taking Shanghai as an Example. Journal of Northwest University for Nationalities (Philosophy and Social Science Edition), (02): 139-148.

[3] Hu L, Pang F, Liu Z, et al., 2019, Research Group of Hubei Provincial Taxation Bureau, State Administration of Taxation. Analysis on Tax Indicators of Business Environment Report of the World Bank and Scores in China. Tax Research, (01): 80-85.

[4] Liu L, Yang J, 2020, Research on China's Tax Collection and Management Innovation Driven by Blockchain Technology - From the Perspective of Optimizing the Tax Business Environment. Friends of Accounting, (22): 154-160.

[5] Mao S, 2020, Legalization Path for Optimizing China's Tax Business Environment. China Price, (07): 31-34. 